\title{
Finite element analysis of the pre-stressed concrete box-girder bridge with corrugated steel webs
}

\author{
Shuqin $\mathrm{LI}^{1, *}$ \\ 1, ${ }^{\star}$ School of Automotive and Traffic Engineering, Hefei University of Technology,Hefei 230009, \\ China
}

Keywords: Bridge engineering; PC composite box - girder; corrugated steel webs; finite element modeling

Abstract: PC box-girder bridge with corrugated steel web has a very good mechanical characteristics and workability, which can achieve good social and economic benefits and has get rapid expansion in China. In this paper, a numerical model of PC composite box girder bridge with corrugated steel web was established by using the finite element software, the analysis and calculation of structure were carried on, and the reference for future similar bridge was provided.

\section{Introduction}

PC composite box girder with corrugated steel webs as a new type of steel-concrete composite structure, full use of the concrete compressive strength, the advantages of high phase binding strength corrugated steel web shear yield, efficient steel and concrete two materials combined, weaknesses, improve material utilization efficiency, is an economic, rational and efficient form of structure; In addition, the corrugated steel webs enhances the three-dimensional box girders, making the bridge more beautiful appearance, is a worthy new bridge structure ${ }^{[1][2][3]}$. Therefore, in recent years this bridge in China has been widely promoted and applied ${ }^{[4][5]}$, and also we made a lot of research ${ }^{[6][7][8]}$. At present, it has been completed and the construction of the bridge has reached dozens of class. In this paper, for an existing combination PC box girder bridge with corrugated steel web as an example, using the finite element software to establish a numerical model of PC composite box girder bridge with corrugated steel web, provide a reference for similar bridge structure analysis.

\section{Bridge Overview}

The bridge for the full length $60.0 \mathrm{~m}$, span $15 \mathrm{~m}+30 \mathrm{~m}+15 \mathrm{~m}$ and width $6.0 \mathrm{~m}$ of PC composite continuous box-girder bridge with corrugated steel webs. The whole bridge with double set, Monolithic main beam is a box of four rooms PC composite box-girder with corrugated steel webs, box-girder width $19.99 \mathrm{~m}$ (calculated and discussed herein by $20.0 \mathrm{~m}$ ), Steel Webs spacing $3 \times 4.0 \mathrm{~m}$, cantilever box-girder length $2.0 \mathrm{~m}$; beam height of 1.5 to $2.2 \mathrm{~m}$, beam bottom press quadratic parabola (see Fig. 1).

Box-girder's roof, floor and transverse bulkheads using C50 concrete, the corrugated steel webs and connections using Q345D steel. The corrugated steel webs standard model for 1200, the thickness is $14 \mathrm{~mm}$; the corrugated steel webs and the concrete ceiling connected by "T-PBL" fittings, floor boards connected by welding with an embedded connector (see Fig. 2), connector plate thickness $14 \mathrm{~mm}$. Box-girder's steel are arranged into two categories: in vivo and in vitro prestressed

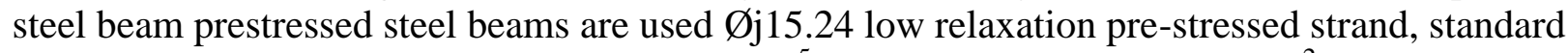
strength $1860 \mathrm{MPa}$, modulus of elasticity $1.9 \times 10^{5} \mathrm{MPa}$, nominal area of $140 \mathrm{~mm}^{2}$.

\section{Finite Element Modeling and Related assumed}

This bridge upper structure adopts the planar truss finite element calculation program Dr Bridge 3.0 calculation. The whole bridge is divided into 120 units, 121 nodes. A lot of testing and documentation has proven PC composite box - girder with corrugated steel webs having accordion (folding) effects to meet the plane section assumption. Finite element modeling process, without 
considering the steel web of beam bending, bending performance that the main beam is completely provided by the top and bottom of concrete, stress, deformation and bearing capacity calculation results of the model are assumed on this basis.

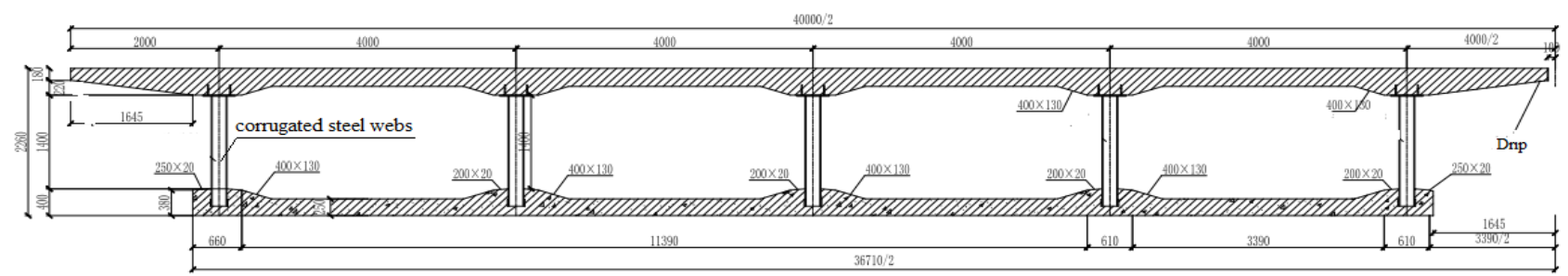

a) in the midspan cross cross-section

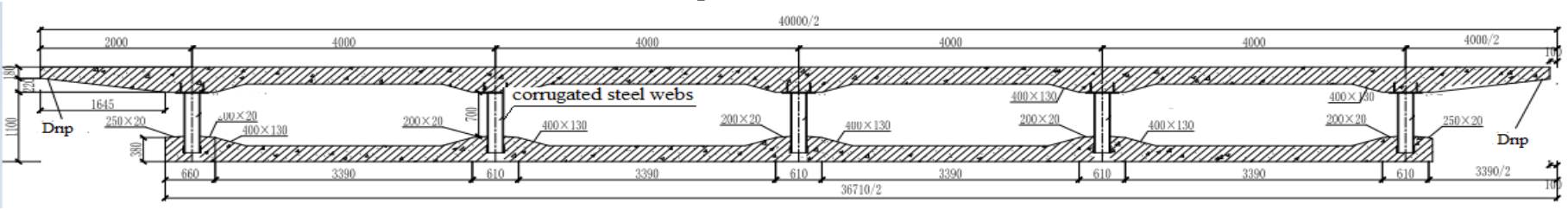

b) in the midspan pier top Cross-sectional

Figure 1. midspan cross-sectional

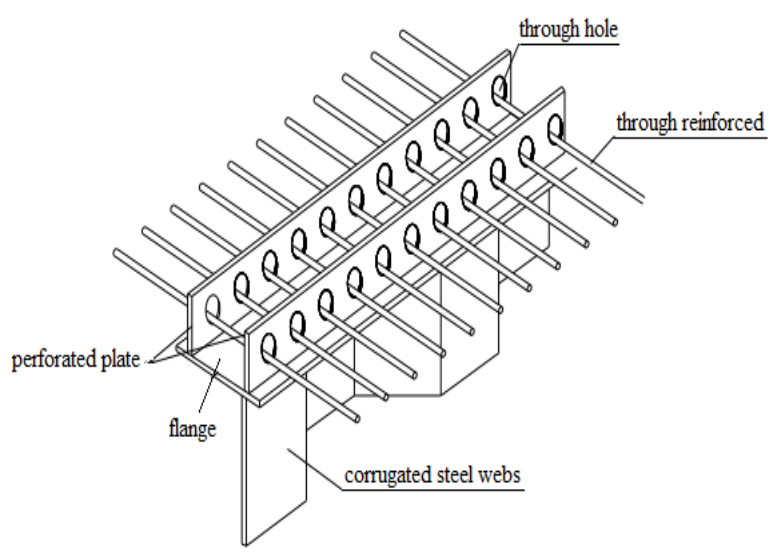

a) corrugated Steel Web and roof connection

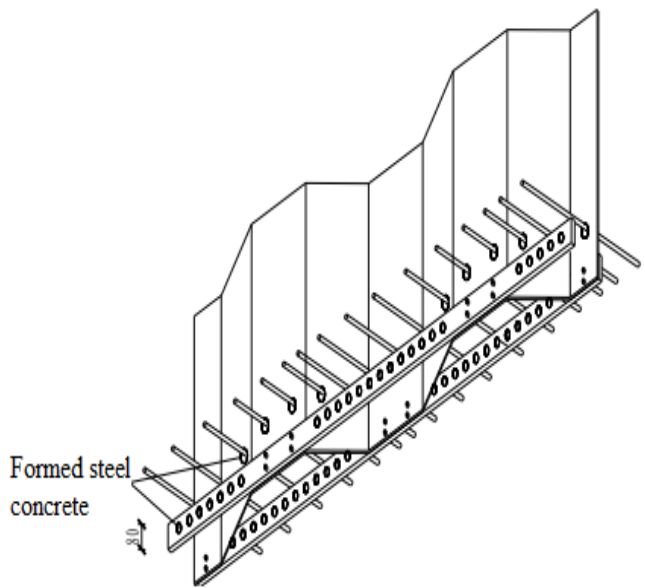

b) corrugated steel webs and backplane connector

Figure 2. Shear connector

Full bridge using a bridge way down, construction is divided into five phases:

Construction stage 1: install all of the cells 1-120 \#, Constraints imposed on the fulcrum, horizontal beam's weight considerate in the form of concentrated load;

Construction stage 2: Tension composite box girder's vivo prestressed tendon;

Construction stage 3: Tension composite box girder's vitro prestressed tendon; Construction stage 4: Applying pavement, sidewalks, railings and other two dead load, according to the uniformly distributed load $q=140 \mathrm{kN} / \mathrm{m}$ consideration;

Construction stage5: Creep Effect.

Creeping makeover Number: (3650 days) 10 years;

Overall warming temperature difference $20{ }^{\circ} \mathrm{C}$, the overall cooling temperature difference $10{ }^{\circ} \mathrm{C}$;

Non-linear temperature: Deck heating $14{ }^{\circ} \mathrm{C}$, cooling $7{ }^{\circ} \mathrm{C}$;

Supports uneven settlement: consider each holder may settle $5 \mathrm{~mm}$.

\section{Calculation results}

\subsection{The checking of the strength of normal section in the limit state of bearing capacity}


Bearing capacity limit state combination: Combination I: basic composition, according to specifications JTG D60-2004 Article 4.1.6.

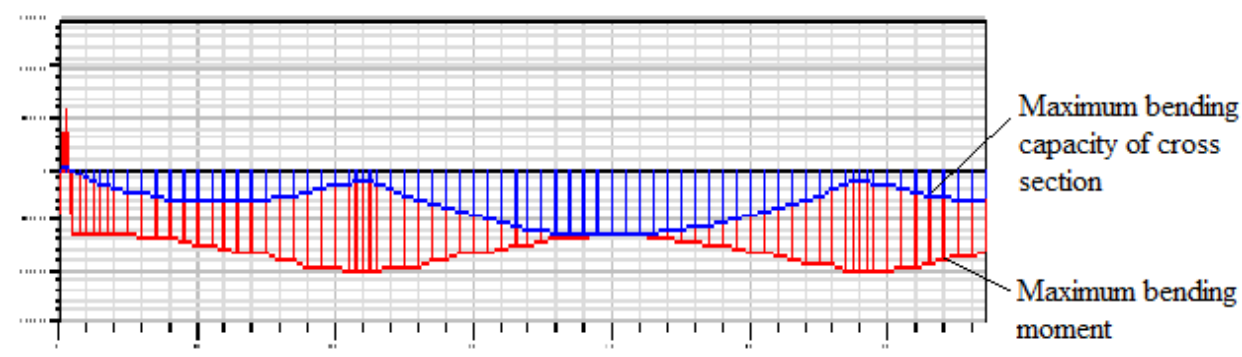

Figure 3 Maximum bending capacity of cross-section and the corresponding maximum bending moment

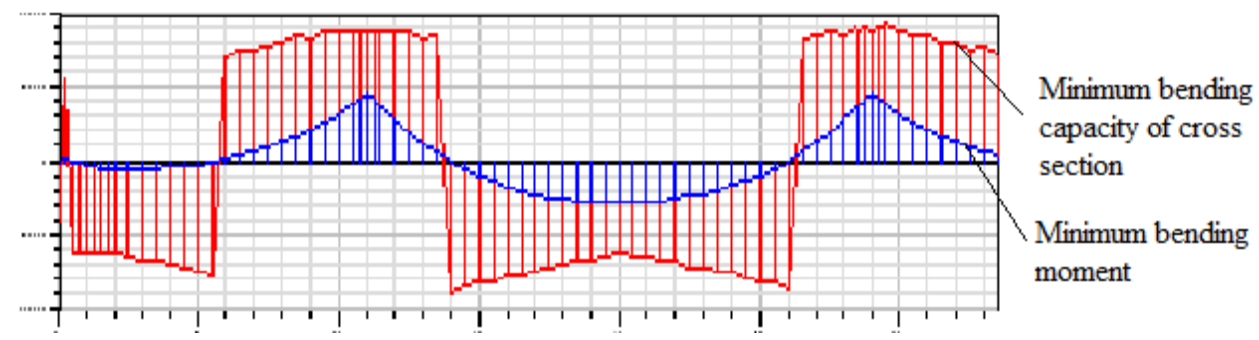

Figure 4 Minimum bending capacity of cross-section and corresponding minimum bending moment

From Figure 3 to figure 4 shows that the bending capacity of main cross section of each section meet the requirements.

\subsection{Stress checking}

(1)Checking calculation of normal stress under combination of short-term effect

The maximum stress on the flange unit: $10.1 \mathrm{Mpa}$;

The minimum stress on the flange unit: $-2.52 \mathrm{e}-02 \mathrm{Mpa}$;

The maximum stress on the lower flange unit: $8.49 \mathrm{Mpa}$;

The minimum stress on the lower flange unit: -7.6e-04 Mpa.

Under the combination of short-term effects, the main girder flange on each cross section edge of minimum and maximum stress and lower flange unit's maximum and minimum normal stress within specification limits.

(2)Checking calculation of normal stress under combination of long-term effect

The maximum stress on the flange unit: $6.25 \mathrm{Mpa}$;

The minimum stress on the flange unit: $3.58 \mathrm{Mpa}$;

The maximum stress on the lower flange unit: $6.73 \mathrm{Mpa}$;

The minimum stress on the lower flange unit: $2.68 \mathrm{Mpa}$.

Under the combination of long-term effects, the main girder flange on each cross section edge of minimum and maximum stress and lower flange unit's maximum and minimum normal stress within specification limits.

(3) Checking calculation of normal stress under standard combination

The maximum stress on the flange unit: $11.6 \mathrm{Mpa}$;

The minimum stress on the flange unit: $0.283 \mathrm{Mpa}$;

The maximum stress on the lower flange unit: $8.68 \mathrm{Mpa}$;

The minimum stress on the lower flange unit: $0.159 \mathrm{Mpa}$.

Under the standard combination, the main girder flange on each cross section edge of minimum and maximum stress and lower flange unit's maximum and minimum normal stress within specification limits.

(4) Bearing reaction force as shown in table 1

4.3 Calculation results of prestressed tendon

(1) Prestressed Tendon Elongation and length as shown in table 2 
Table. 1 Bearing reaction force

\begin{tabular}{|l|l|}
\hline Bearing No. & Basic combination \\
\hline 1 & $9.16 \mathrm{E}+03$ \\
\hline 31 & $2.88 \mathrm{E}+04$ \\
\hline 91 & $2.88 \mathrm{E}+04$ \\
\hline 121 & $9.16 \mathrm{E}+03$ \\
\hline
\end{tabular}

Table. 2 Prestressed Tendon Elongation and length

\begin{tabular}{|l|l|l|l|l|}
\hline $\begin{array}{l}\text { Prestressed } \\
\text { Tendon } \\
\text { No. }\end{array}$ & $\begin{array}{l}\text { Prestressed Tendon } \\
\text { Curve length }\end{array}$ & $\begin{array}{l}\text { The left end of the } \\
\text { elongation }\end{array}$ & $\begin{array}{l}\text { The right end of } \\
\text { the elongation }\end{array}$ & $\begin{array}{l}\text { Total } \\
\text { elongatio } \\
\mathrm{n}\end{array}$ \\
\hline 1 & 60 & 0.197 & 0.197 & 0.395 \\
\hline 2 & 60.1 & 0.191 & 0.191 & 0.382 \\
\hline 3 & 60.4 & 0.103 & 0.102 & 0.205 \\
\hline 4 & 60.3 & 0.105 & 0.104 & 0.209 \\
\hline 5 & 12 & $3.99 \mathrm{E}-02$ & $3.99 \mathrm{E}-02$ & $7.99 \mathrm{E}-02$ \\
\hline 6 & 12 & $3.99 \mathrm{E}-02$ & $3.99 \mathrm{E}-02$ & $7.99 \mathrm{E}-02$ \\
\hline
\end{tabular}

(2) Checking calculation of maximum tensile stress of prestressed tendon as shown in table 3

Table. 3 Maximum tensile stress of prestressed tendon

\begin{tabular}{|c|c|c|c|}
\hline Prestressed Tendon No. & Maximum computational stress (Mpa) & Allowable maximum stress (Mpa) & Whether to meet \\
\hline 1 & $-1.15 \mathrm{E}+03$ & $-1.21 \mathrm{E}+03$ & Yes \\
\hline 2 & $-1.15 \mathrm{E}+03$ & $-1.21 \mathrm{E}+03$ & Yes \\
\hline 3 & -580 & $-1.21 \mathrm{E}+03$ & Yes \\
\hline 4 & -605 & $-1.21 \mathrm{E}+03$ & Yes \\
\hline 5 & $-1.01 \mathrm{E}+03$ & $-1.21 \mathrm{E}+03$ & Yes \\
\hline 6 & $-1.01 \mathrm{E}+03$ & $-1.21 \mathrm{E}+03$ & Yes \\
\hline
\end{tabular}

\subsection{Bridge structure displacement}

(1) Bridge deflection

According to the new "Highway Bridge Design General specifications" section 6.5.3 stipulates that flexural member's deflection during use should be considered long-term effects of the load. C50 concrete is applied in this bridge, its deflection long-term growth coefficient is $\eta \theta=1.425$, After eliminating the long-term deflection of structure weight generated, the maximum deflection of the girder should not exceed the calculated span of 1/600(See Table 4).

Table.4 Maximum deflection of main girder After eliminating the long-term deflection of structure weight generated

\begin{tabular}{|c|c|c|c|c|}
\hline $\begin{array}{c}\text { Node } \\
\text { No. }\end{array}$ & position & $\begin{array}{c}\text { Structural deflection after eliminating the } \\
\text { structural weight }(\mathrm{mm})\end{array}$ & $\begin{array}{c}\text { Allowed values } \\
(\mathrm{mm})\end{array}$ & $\begin{array}{c}\text { Whether to } \\
\text { meet }\end{array}$ \\
\hline 17 & Cross of left sidespan & -0.199 & 25 & Yes \\
\hline 61 & Cross of midspan & -1.06 & 50 & Yes \\
\hline 106 & Cross of right sidespan & -0.204 & 25 & Yes \\
\hline
\end{tabular}

(2) Long-term deflection and prestressing camber setting under load combination of short-term effects(See Table 4).

Article 6.5.5 norms, Prestressing camber is not set when the long - term arch value which produced by prestressing force of the prestressed concrete flexural member is larger than the long term deflection which calculated under load combination of short-term effect; when the long - term arch value which produced by prestressing force of the prestressed concrete flexural member is less than the long - term deflection which calculated under load combination of short-term effect, the prestressing camber should be set according to the difference between the long-term deflection which calculated under load combination of short-term effects and the long - term arch value which produced by prestressing force. 
Table.5 Prestressing camber

\begin{tabular}{|c|c|c|c|c|c|}
\hline $\begin{array}{c}\text { Node } \\
\text { No. }\end{array}$ & $\begin{array}{c}\text { Long-term deflection } \\
\text { under load combination of } \\
\text { short-term effects (mm) }\end{array}$ & $\begin{array}{c}\text { the long - term arch value } \\
\text { which produced by } \\
\text { prestressing force }(\mathrm{mm})\end{array}$ & $\begin{array}{c}\text { Structural deflection } \\
\text { after eliminating the } \\
\text { structural weight } \\
(\mathrm{mm})\end{array}$ & $\begin{array}{c}\text { Whether to set } \\
\text { the prestressing } \\
\text { camber }\end{array}$ & $\begin{array}{c}\text { prestressing } \\
\text { camber (mm) }\end{array}$ \\
\hline 17 & 0.549 & 1 & -0.199 & Yes & 2.34 \\
\hline 61 & -9.45 & 2 & -1.06 & Yes & -6.83 \\
\hline 106 & 0.498 & 1 & -0.204 & Yes & 2.38 \\
\hline
\end{tabular}

\section{Summary}

Through the above calculation and analysis, it can be concluded that:

(1) the bending capacity of each section is larger than that of the carrying capacity, and the cross section bearing capacity meets the requirements of the specification;

(2)Under the combination of short-term effects, the main girder flange on each cross section edge of minimum and maximum stress and lower flange unit's maximum and minimum normal stress within specification limits.

(3)Under the combination of long-term effects, the main girder flange on each cross section edge of minimum and maximum stress and lower flange unit's maximum and minimum normal stress within specification limits.

(4) The maximum deflection of the bridge structure is less than the specification limit.

\section{Acknowledgement}

The presented research greatly appreciates the financial support by Anhui province natural science foundation of China (Grant No. 1608085QE103) and Doctorates special assistance fund of Hefei University of Technology (Grant No. 121-4115100004).

\section{References}

[1] PC bridge with corrugated steel webs planned [maniyuaru] (plan). TOKYO: Research Institute of the Composite Girder Bridge with Corrugated Steel Web, 1998. (in Japanese)

[2] Jin Zi-Renzhi. PAFOBONDORIBU junction adopted corrugated steel web wart construction of the bridge TOKYO: Research Institute of the Composite Girder Bridge with Corrugated SteelWeb, 1998, 73. (in Japanese)

[3] LI Shu-qin, Research on structural design and shear connectors of the PC box-girder bridge with corrugated steel webs[D].NANJING: Southeast University, 2012.

[4] LI Shu-qin, CHEN Jian-bin, WAN Shui, CHEN Hua-li. Application of the pre-stressed concrete box-girder with corrugated steel webs in bridge engineering in china $[\mathrm{J}]$. Engineering mechanics.2009(A01):115-118.

[5] WAN Shui, LI Shu qin, MA Lei. Application of P restress e d Concrete Composite Box girder Structure with Corrugated Steel Webs in Bridge Engineering in China[J]. Journal of Architecture and Civil Engineering. 2009, 26(2):15-20.

[6] WAN Shui, TANG Yi, WANG Jinsong. Experimental Test of Structural Property of Prestressed Concrete Box girder with Corrugated Steel Webs [ J ] .Journal of Nanjing University of Science and Technology, 2004,28 ( 5) : 498-501.

[7] Yuan Anhua, Chen Jianbing, Wan Shui, Lu Bingcan. On a design of pre-stressed concrete composite continuous box-girder footbridge with corrugated steel webs [J].Journal of University of Science and Technology of Suzhou (Engineering and Technology), 2004, 17(3): 55-58. (in Chinese) [8] Zhu Gaobo. A dissertation submitted to southeast university for the academicdegree of master of engineering [D]. Nanjing: Southeast University, 2007. (in Chinese) 